\title{
IMPLIKATUR KONVENSIONAL BERMODUS IMPERATIF PADA TUTURAN MOTIVASI MERRY RIANA DAN RELEVANSINYA TERHADAP PEMBELAJARAN BAHASA INDONESIA
}

\section{IMPERATIVE MODELING CONVENTIONAL IMPLICATIONS ON MERRY RIANA MOTIVATION AND ITS RELEVANCE TOWARDS INDONESIAN LEARNING}

\author{
Defi Putri Rahmawati ${ }^{1}$, Idhoofiyatul Fatin ${ }^{2 *}$, M. Ridlwan ${ }^{3}$ \\ Pendidikan Bahasa dan Sastra Indonesia, Universitas Muhammadiyah Surabaya, \\ Indonesia ${ }^{1,2,3}$ \\ defiputrirahmawati@gmail.com ${ }^{1}$, idhofatin.pbsi@ fkip.um-surabaya.ac.id $^{2}$, \\ iezhaqlagi@gmail.com ${ }^{3}$ \\ *penulis korespondensi
}

\begin{tabular}{ll}
\hline Info Artikel & ABSTRAK \\
\hline Sejarah artikel: & Penelitian ini bertujuan untuk mendeskripsikan implikatur konvensional \\
Diterima: & bermodus imperatif pada tuturan motivasi Merry Riana pada acara Metro \\
11 Juni 2020 & Tv I'm Impossible pada bulan Februari dan Maret tahun 2019 yang diunggah \\
Direvisi: & di youtube. Selain itu juga mendeskripsikan relevansinya terhadap \\
20 Juni 2020 & pembelajaran Bahasa Indonesia. Penelitian ini menggunakan metode \\
Disetujui: & penelitian deskriptif kualitatif dan mengunakan langkah-langkah \\
20 Juli 2020 & menganalis data yang meliputi reduksi, penyajian data, penarikan hasil \\
& kesimpulan. Berdasarkan hasil pembahasan, diketahui bahwa terdapat tiga \\
Kata kunci: & jenis implikatur konvensional bermodus imperatif pada tuturan motivasi \\
Implikatur & Merry Riana, yaitu perintah, ajakan, dan permintaan. Di antara ketiganya, \\
konvensional, & yang paling dominan adalah perintah. Dalam pembelajaran Bahasa \\
imperatif, motivasi & Indonesia, implikatur konvensional bermodus imperatif pada tuturan \\
& motivasi Merry Riana ini relevan dengan salah satu pokok bahasan untuk \\
& mendukung tercapainya KD 3.3., 4.3., 3.4. dan 4.4 yang berkaitan dengan \\
& pidato persuasif di kelas IX SMP.
\end{tabular}

\begin{tabular}{ll}
\hline Article Info & ABSTRACT \\
\hline Article history: & This study aims to describe the conventional implications of the imperative \\
Received: & mode on Merry Riana's motivational utterances on the Metro TV I'm \\
11 June 2020 & Impossible program in February and March 2019 which were uploaded on \\
Revised: & YouTube. It also describes their relevance to learning Indonesian. This \\
20 June 2020 & study uses descriptive qualitative research methods and uses several steps to \\
Accepted: & analyze data which includes reduction, data presentation, drawing \\
20 July 2020 & conclusions. Based on the results of the discussion, it was stated that there \\
& were three types of conventional implications with imperative modes in \\
Keyword: & Merry Riana's motivational utterances, namely commands, invitations, and \\
conventional & requests. Among the three categories, the most dominant is the command. \\
implications, & In learning Indonesian, the conventional implication of the imperative mode \\
imperative, & in Merry Riana's motivational speech is relevant to one of the subjects to \\
motivation & support the achievement of KD 3.3, 4.3, 3.4. and 4.4 which related to \\
& persuasive speeches.
\end{tabular}

Copyright @ 2020, Stilistika: Jurnal Pendidikan Bahasa dan Sastra DOI: http://dx.doi.org/10.30651/st.v13i2.5357 


\section{PENDAHULUAN}

Penggunaan implikatur dalam berbahasa bukan hanya sebuah kesengajaan, akan tetapi memiliki pertimbangan tersendiri seperti untuk memperhalus tuturan, menjaga etika kesopanan, dan menjaga agar tidak menyinggung perasaan pendengar ataupun mitra tutur secara langsung. Implikatur di dalamnya mengandung suatu modus tuturan yang tersirat dalam suatu ujaran, ujaran tersebut mampu menggerakkan mitra tuturnya untuk melakukan apa yang dimaksudkan oleh penutur kepada mitra tuturnya.

Praktik berkomunikasi memiliki motif tertentu yang ingin diungkapkan oleh seseorang, baik disampaikan secara langsung atau secara tersirat. Gerungan (1991:40) mengatakan bahwa semua tingkah laku dan perbuatan dari setiap manusia pada hakikatnya mempunyai motif dibaliknya. Penggunaan implikatur ini sengaja diciptakan untuk dapat memberikan dorongan pada mitra tutur untuk mempercayai atau yakin terhadap tuturan penutur. Salah satu motivator yang sukses menggunakan tuturan motivasi ini adalah Merry Riana.

Melalui jejaring sosial, Merry Riana telah mendapatkan pengikut yang berjumlah lebih dari 1,5 juta lebih subscribe pada akun youtube pribadinya. Merry Riana menggunakan pilihan diksi yang indah juga memiliki ciri khas yaitu kata-kata yang diujarkan seperti syair pantun yang bersajak a-aa-a atau ab-ab. Merry Riana juga mengungkapkan maksud atau makana dari ungkapannya secara tersembunyi, artinya Merry Riana tidak memaparkan secara langsung maksud dan tujuan dari ungkapannya tetapi dengan menggunakan kata-kata yang konotasi untuk menarik perhatian para pendengar sehingga orang yang mendengarkan terpengaruh oleh apa yang diungkapkannya. Memotivasi bagi Merry Riana harus menggunakan makna kata secara implisit, dengan alasan untuk menarik perhatian para pendengar. Menggunakan kata-kata yang bermakna akan membuat orang semakin penasaran, dan memiliki keinginan untuk mengetahui apa isi yang ada dalam motivasi tesebut. Tuturan yang digunakan Merry Riana untuk memotivasi dipilih secara selektif, hal itu dilakukan agar ungkapan motivasinya dapat memberikan dorongan semangat serta memberikan pengaruh yang positif. Sadirman

(2006:73)

mengatakan motivasi itu sebagai perubahan energi dalam diri seseorang yang ditandai dengan tanggapan terhadap sesuatu dengan apa adanya tanpa tujuan apapun. Motivasi ini merupakan bagian dari implikatur. Yule (1998:40) mengungkapkan bahwa implikatur adalah sebuah implikasi makna tersirat secara konteks dan makna itu bukan bagian atas apa yang dituturkan. Implikatur juga diartikan sebagai implikasi makna berupa satuan pragmatik dari suatu tuturan, baik lisan maupun tulisan. Grice (dalam Rohmadi 2017:60) menyatakan implikatur terdiri dari dua jenis, yaitu implikatur konvensional dan implikatur implikatur nonkonvensional. Implikatur konvensional tergantung pada kondisi kebenaran dalam penggunaan kata atau makna, bentuk-bentuk tertentu dan ekspresi dari suatu tuturan dalam percakapan. Implikatur nonkonvensional berdasarkan pada prinsip yang mengatur perilaku yang tepat sesuai dengan konteks dari suatu percakapan. 
Modus tuturan adalah sebuah cara untuk mengungkapkan suasana psikologis perbuatan yang terkandung dalam sebuah tuturan menurut tafsiran penutur atau sikap penuturnya. Secara formal Wijana (1996:32) membedakan tuturan berdasarkan modusnya menjadi tiga yakni, tuturan bermodus deklaratif, modus interogatif, dan modus imperatif. Tuturan motivasi Merry Riana banyak yang bermodus imperatif yang berupa nasihat ajakan, nasihat perintah, dan nasihat permintaaan.

Motivasi dapat diungkapkan secara lisan dan tertulis baik langsung maupun tidak langsung. Berkaitan dengan hal tersebut dipilih motivasi yang disampaikan secara lisan oleh Merry Riana dalam media sosial youtube dalam acara yang ditayangkan di Metro Tv yaitu I'm Impossible. Alasan dipilih acara tersebut karena dalam acara tersebut ada interaksi antara Merry Riana (motivator) dengan audien sehingga peneliti bisa mengamati secara keseluruhan.

$\begin{array}{ccr}\text { Grice } & \text { dalam } & \text { Rohmadi } \\ (2017: 60) & \text { menyatakan } & \text { bahwa }\end{array}$
implikatur dibedakan menjadi dua, yaitu implikatur konvensional dan nonkonvensional. Grice (1975:45) juga menyatakan bahwa dalam implikatur terdapat dua jenis, yaitu conventional implicature (implikatur konvensional) dan conversational implicature (implikatur non konvensional).

Lyons (1995:272) menjelaskan perbedaan antara kedua implikatur tersebut yaitu bahwa bentuk implikatur konvensional tergantung pada kondisi kebenaran dalam penggunaan kata atau makna, bentuk-bentuk tertentu dan ekspresi dari suatu tuturan dalam percakapan. Implikatur nonkonvensional berdasarkan pada prinsip yang mengatur perilaku yang tepat sesuai dengan konteks dari suatu percakapan. Berdasarkan penjelasan tersebut disimpulkan bahwa implikatur konvensional adalah implikatur yang menjelaskan makna kata secara implisit, bukan dari makna pelanggaran prinsip percakapan. Adapun implikatur nonkonvensional adalah implikatur yang diperoleh dari fungsi pragmatis yang tersirat dalam percakapan. Implikatur konvensional dikaitkan dengan pemakaian dan pemaknaan umum, sementara implikatur percakapan merujuk pada prinsilprinsip dalam pertuturan secara tepat.

Implikatur konvensional adalah Implikatur konvensional yang mengacu pada makna kata secara konvensional, makna percakapan ditentukan oleh arti konvensional (kata-kata yang digunakan). Implikasi dari suata ujaran bersifat konvensional, artinya semua orang pada umumnya sudah mengetahui dan memahami maksud dari suatu ujaran (Rohmadi 2017:60). Berdasarkan penjelasan tersebut disimpulkan bahwa pemahaman terhadap implikasi dari makna kata bersifat konvensional, maksudnya meskipun suatu ujaran mempunyai makna yang implisit tetapi secara umum orang bisa memahami maksud dari ujaran tersebut.

Grice dalam Rani (2004:171) menyatakan bahwa dalam penggunaan bahasa terdapat implikatur yang disebut implikatur konvensional, yaitu implikatur tersebut ditentukan oleh arti konvensional dari kata-kata yang dipakai. Suatu leksikal yang terdapat dalam suatu bentuk ujaran, dapat dikenali implikasinya karena makna dari ujaran tersebut berasal dari ujaran yang maknanya sudah diketahui secara umum. Sehubungan dengan pernyataan tersebut Mulyana (2005:12) berpendapat bahwa implikatur konvensional bersifat umum yang 
artinya secara umum orang sudah mengetahui maksud dan makna sesuatu hal tersebut dalam suatu tuturan. Selanjutnya, modus imperatif adalah kalimat yang diujarkan oleh seorang penutur dan dengan harapan agar pendengar atau lawan tutur memberi reaksi dalam bentuk tindakan secara fisik. Modus imperatif digunakan untuk memerintah, mengajak, dan memerintah atau memohon. Secara konvensional ditandai dengan tanda seru dan diucapkan dengan intonasi naik. Keenam kata (yakni, ayo, biar, coba, harap, hendaklah, hendaknya, lah, mari, mohon, silakan, dan tolong). Imperatif di dalam bahasa Indonesia biasanya juga digunakan bersama dengan kata-kata atau ungkapan tertentu yang lazim disebut penandapenanda kesantunan. Berdasarkan berberapa modus tersebut peneliti hanya menggunanakan modus imperatif sebagai kajian dalam penelitian ini. Motivasi Merry Riana didalamnya mengandung tuturan yang bersisikan perintah, ajakan dan permintaan atau permohonan.

Penelitian tidak beranjak dari awal, umumnya penelitian telah ada acuan yang mendasarinya. Hal ini bertujuan sebagai titik tolak untuk mengadakan suatu penelitian, sangat perlu meninjau penelitian yang telah ada. Penelitian yang digunakan sebagai acuan dalam penelitian ini, diantaranya adalah penelitian skripsi dan jurnal sebagai berikut.

Albani Nur Aeni (2015) yang berjudul "Analisis Implikatur pada Tuturan Kata Bijak Mario Teguh dalam Acara Talk Show Mario Teguh Golden Ways di Metro TV". Penelitian tersebut mendeskripsikan bentuk implikatur yang terkandung pada tuturan kata bijak Mario Teguh di dalam acara Talk Show Mario Teguh Golden Ways.
Penelitian tersebut menjelaskan implikatur dan maksud implikasi dari tuturan motivasi. Perbedaanya terletak pada data penelitian, data yang digunakan Albani adalah tuturan bijak Mario Teguh sedangkan penelitian ini menggunakan data ungkapan motivasi Merry Riana.

Eva Nur Khasanah (2016) yang berjudul "Implikatur dan Daya Pragmatik di Balik Ungkapan Motivasi Berorganisasi Kalangan Peserta Didik." Penelitian tersebut menjelaskan bentuk implikatur yang terdapat di balik ungkapan motivasi kalangan peserta didik berlatar belakang budaya Jawa adalah implikatur konvensional representatif dan implikatur konvensional komisif. Perbedaan penelitian terletak pada data yang digunakan untuk penelitian, subjek yang digunakan oleh Eva adalah ungkapan peserta didik, sedangkan penelitian ini menggunakan subjek ungkapan motivasi seorang motivator.

\section{METODE}

Penelitian ini menggunakan metode penelitian deskripstif kualitatif karena penelitian ini mendeskripsikan implikatur yang bermodus imperatif yang terdapat pada tuturan motivasi Merry Riana, selain itu penelitian ini juga bersifat induktif yang hasilnya lebih menekankan pada makna dari tuturan motivasi.

Penelitian kualitatif ini, kegiatannya dilakukan secara sadar, terarah dan bertujuan untuk memperoleh suatu informasi yang diperlukan. Sumber data pada penelitian ini adalah tuturan motivasi Merry Riana pada acara Metro Tv I'm Impossible yang ada di media sosial akun youtube pribadi Merry Riana mulai bulan Februari sampai Maret 
2019 yang akan dikaji dari sudut implikatur.

Pada penelitian ini peneliti memilih lima tema video yang ada dalam acara Metro Tv I'm Impossible sebagai beriku.

1. Sedih itu Boleh Tapi Putus Asa Jangan

2. Pagi-pagi Happy

3. Kegedean Gengsi

4. Ibu Rumah Tangga Vs Ibu Bekerja

5. Maju Terus Pantang Mundur

Penelitian ini menggunakan metode dokumentasi terekam untuk mencari data tentang implikatur tuturan motivasi Merry Riana pada acara Metro Tv I'm Impossible yang ada di media sosial youtube pada akun pribadi Merry Riana.

Teknik pengolahan data yang dilakukan yang dilakukan dalam penelitian ini sebagai berikut:

1. Editing yaitu data yang telah terkumpul di edit kembali, hal ini bertujuan untuk bertujuan untuk meneliti kembali data yang telah terkumpul dan memeriksa kembali apakah data yang terkumpul sudah sesuai berupa implikatur konvensional dan nonkonvensional yang bermodus imperatif.

2. Koding yaitu memberikan pengkodean terhadap hasil data dari dokumentasi yakni berupa video tuturan motivasi Merry Riana pada acara Metro Tv I'm Impossible yang ada di media sosial akun youtube pribadi Merry Riana. Cara penulisan kode yaitu jenis implikatur/jenis imperatif/jenis fungsi tuturan/tema video/segmen/waktu.

3. Interpretasi yaitu memberikan jawaban berupa penjabaran mengenai data yang telah terkumpul sesuai dengan fokus penelitian yaitu jenis implikatur yang bermodus imperatif dan fungsi tuturan..

\section{HASIL DAN PEMBAHASAN}

Implikatur konvensional adalah makna yang tidak terungkap dari penutur akan tetapi secara umum orang dapat memahaminya dari apa yang dimaksudkan oleh penutur dalam suatu percakapan. Modus imperatif digunakan untuk memerintah, mengajak, dan memerintah atau memohon. Secara konvensional ditandai dengan tanda seru dan diucapkan dengan intonasi naik. Keenam kata (yakni, ayo, biar, coba, harap, hendaklah, hendaknya, lah, mari, mohon, silakan, dan tolong). Imperatif di dalam bahasa Indonesia biasanya juga digunakan bersama dengan katakata atau ungkapan tertentu yang lazim disebut penanda-penanda kesantunan.

\section{Implikatur Konvensional Bermodus Imperatif Perintah}

Kalimat perintah merupakan kalimat yang bertujuan untuk memerintah mitra tutur agar mau melakukan apa yang penutur inginkan. Imperatif perintah juga dapat dikenali dari pemakaian bentuk-bentuk tata bahasanya, misalnya tidak digunakannya bentuk awalan Men-, dan sering digunakannya partikel -lah pada kalimat imperatif. Pada tuturan ini menggunakan sebuah kalimat perintah dalam tuturannya. Dalam hal ini si penutur memerintah kepada si mitra tutur untuk melakukan apa yang diperintah oleh si penutur. Berikut adalah tuturan yang mengandung imeratif perintah.

11. MR : "Yang lalu biarlah berlalu, karena yang indah sudah menunggumu. Jadi jangan biarkan beban lalu itu menghantui, bahkan memberatkan hari ini. Hadapi dan syukuri. Ok? 
AU : "Ok."

IF : "Hadapi dan syukuri, paling tidak kita bisa merilis beban-beban sebelumnya ya? MR : "Ya.

(Imk/Ph/Drk/PPHP/2/08.08-

Tuturan yang bernomor 11 tersebut merupakan tuturan Merry Riana yang diambil di youtube pada acara I'm Impossible di Metro Tv yang bertema Pagi-pagi Happy part 2 yang berjudul "Hidup Bukan untuk Ditangisi Tapi Untuk Disyukuri”. Tuturan tersebut dituturkan oleh Merry Riana setelah Merry Riana bertanya ke Audien "Apakah dalam hidup kalian punya beban?" Kemudian Audien menjawab "punya." Merry Riana menjelaskan bahwa dalam kehidupan ini pasti memiliki masalah, jika masalah yang lalu masih dibawa sampai sekarang justru masalahmu akan lebih berat, kemudian Merry Riana menuturkan "Yang lalu biarlah berlalu, karena yang indah sudah menunggumu. Jadi jangan biarkan beban lalu itu menghantui, bahkan memberatkan hari ini. Hadapi dan syukuri. Ok?

Tuturan bernomor 11 tersebut termasuk implikatur konvensional karena Audien sudah memahami maksud dari tuturan Merry Riana yang implisit tanpa ada penjelasan tambahan, dan Audie juga merespon tuturan Merry Riana dengan jawaban " $o k$ ”.

Tuturan tersebut bermodus imperatif perintah karena Merry Riana memerintahkan seseorang untuk bisa melupakan masa lalu, dan menghadapi serta mensyukuri apa yang saat ini terjadi dalam hidup. Berdasarkan modusnya yang berupa imperatif perintah maka tuturan tersebut memiliki fungsi tuturan direktif yang berupa perintah.

Berbeda dengan tuturan bernomor 11 tuturan berikut ini juga merupakan tuturan yang bermodus imperatif perintah akan tetapi berbeda tema dengan tuturan bernomor 11 . Tuturan berikut diambil dari youtube pada acara Metro Tv I'm Impossible dengan tema Kegedan Gengsi part 2 yang berjudul "Gengsi Sama Pekerjaan Anda Saat Ini. Tuturan tersebut seperti di bawah ini;

15. MR : "Kalau Anda tidak bisa melakukan hal yang besar, lakukannlah hal yang kecil dengan jiwa yang besar. Nggak perlu gengsi, nggak perlu perduli apa kata orang

AU : "Ok."

(Imk/Ph/Drk/KKGS/1/08.48-

Berdasarkan tuturan yang bernomor 15 tersebut, dituturkan oleh Merry Riana untuk menjelaskan tuturan sebelumnya yang menjelaskan bahwa seperti apa masa depan seseorang bergantung dari apa yang dilakukan saat ini, oleh karena itu lakukanlah sesuatu yang bermanfaat saat ini agar di masa depan hidupnya jadi lebih baik. Kemudian Merry Riana menuturkan "Kalau Anda tidak bisa melakukan hal yang besar, lakukannlah hal yang kecil dengan jiwa yang besar. Nggak perlu gengsi, nggak perlu perduli apa kata orang."

Tuturan tersebut berwujud implikatur konvensional karena Audien mengerti apa makna yang dimaksudkan oleh Merry Riana pada tuturan tersebut dan Audien juga menanggapinya dengan jawaban "ok".

Tuturan tersebut bermodus imperatif perintah, hal tersebut dengan 
alasan Merry Riana memerintahkan seseorang untuk melakukan sesuatu hal yang kecil dengan jiwa yang besar maksudnya yaitu jika belum bisa mewujudkan apa yang berguna bagi orang banyak, maka awali dengan melakukan sesuatu hal yang bermanfaat bagi diri sendiri.

Tuturan tersebut memiliki fungsi tuturan direktif yang berupa perintah jika belum bisamelakukan sesuatu hal yang bermanfaat bagi orang banyak, lakukanlah hal yang bermanfaat bagi diri sendiri jangan gengsi untuk melakukannya dan jangan dengarkan perkataan orang lain.

Berbeda dengan tuturan bernomor 15 tuturan berikut ini juga merupakan tuturan yang bermodus imperatif perintah akan tetapi berbeda tema dengan tuturan bernomor 15 . Tuturan berikut diambil dari youtube pada acara Metro Tv I'm Impossible dengan tema Ibu Rumah Tangga Vs Ibu Bekerja part 4 yang berjudul "Dilema Atas Kedua Pilihan". Tuturan tersebut seperti di bawah ini;

21. MR : "Berhentilah membandingkan dan jalanilah setiap pilihan dengan kesungguhan. Stop comparing, karena ingat berbeda bukan berarti ada yang salah dan ada yang benar, jalanilah pilihanmu."

AU : "Ok"

(Imk/Ph/Drk/IRIB/4/03.44-

Tuturan bernomor 21 tersebut dituturkan oleh Merry Riana setelah menjelaskan bahwa setiap orang akan memiliki pilihan yang berbeda baik mau jadi Ibu rumah tangga atau mau jadi Ibu yang bekerja. Keduanya memiliki konsekuensi yang berbeda pula, oleh karena itu sebagai seorang Ibu harus bias menentukan pilihannya sendiri. Kemudian Merry Riana menuturkan "berhentilah membandingkan dan jalanilah setiap pilihan dengan kesungguhan. Stop comparing, karena ingat berbeda bukan berarti ada yang salah dan ada yang benar, jalanilah pilihanmu."

Berdasarkan tuturan yang bernomor 21 tersebut jenis implikaturnya adalah konvensional karena Audien mengerti apa makna yang dimaksudkan oleh Merry Riana pada tuturan tersebut dan Audien juga menanggapinya dengan jawaban "ok". Tuturan tersebut bermodus imperatif perintah karena Merry Riana memerintahkan kita untuk stop comparing yang berarti berhenti membandingkan, meskipun berbeda pendapat, berbeda pemikiran dan berbeda cara melakukan sesuatu jalanilah yang sudah menjadi pilihan setiap orang dengan kesungguhan. Tuturan tersebut memiliki fungsi tuturan direktif yang berupa perintah untuk berhenti membandingkan dan jalanilah setiap pilihan dengan kesungguhan.

\section{Implikatur Konvensional Bermodus Imperatif Ajakan}

Kalimat imperatif ajakan merupakan kalimat imperatif dengan maksud mengajak untuk melakukan suatu tindakan. Kalimat tuturan yang bermakna ajakan ini ditandai dengan penanda kesantunan mari dan ayo. Kedua macam penanda kesantunan itu masing-masing memiliki makna ajakan. Berikut adalah tuturan yang mengandung imeratif ajakan;

1. MR : "Kalo sekarang saat ini Anda mengalami masalah angkat tangan tinggi-tinggi, 
letakkan di dada, tarik nafas dalam-dalam, hembuskan nafasnya. Elus-elus sambil bilang bersyukur karena ada masalah itu artinya apa?"

AU : "Saya masih hidup."

IJ : "Dan Tuhan masih sayang dengan kita."

MR : "Iya Tuhan masih sayang dengan kita."

(Imk/Aj/Drk/SBPJ/1/06.40-

Tuturan yang bernomor 2 tersebut, dituturkan oleh Merry Riana pada acara I'm Impossible yang bertema Sedih Boleh Putus Asa Jangan part 1 yang berjudul "Bersyukur Ketika Ada Masalah". Tuturan tersebut diturkan oleh Merry Riana setelah menjelaskan bahwa hidup itu diibaratkan seperti mesin pendeteksi jantung, yang memiliki gambar di monitor naik turun dan datar. Naik turun memiliki arti bahwa hidup itu pasti mengalami masalah yaitu kegalan dan keberhasilan, sedangkan datar berarti mati. Kemudian Merry Riana menuturkan tuturan yang bernomor 2 tersebut.

Berdasarkan tuturan tersebut, jenis implikaturnya konvensional karena apa yang dikatakan oleh Merry Riana "Kalo sekarang saat ini Anda mengalami masalah angkat tangan tinggi-tinggi, letakkan di dada, tarik nafas dalam-dalam, hembuskan nafasnya. Elus-elus sambil bilang bersyukur karena ada masalah itu artinya apa?", maksud dari tuturan Merry Riana yang bermaksud penjelasan kalau seseorang masih diberikan masalah harus bersyukur karena artinya masih hidup. Audien menjawab "Saya masih hidup". Artinya Audien memahami apa yang diturkan oleh Merry Riana. Tuturan tersebut, bermodus imperatif ajakan yang berupa ajakan untuk angkat tangan tinggitinggi, letakkan di dada, tarik nafas dalam-dalam, hembuskan nafasnya. Perintah tersebut Merry Riana ingin menyadarkan bahwa sekarang harus bersyukur karena masih bisa bernafas.

Berbeda dengan tuturan yang bernomor 2 tuturan berikut juga memiliki imperatif ajakan dengan acara dan tema yang sama akan tetapi part yang berbeda yaitu part 3 yang berjudul "Give Up Or Get Up seperti di bawah ini;

5. IJ : "Sebelum kita lanjutkan, lagi-lagi kita akan Melihat quotes yang dibuat oleh miss Merry Riana, ini dia quotesnya. Di masa sulit kamu hanya punya dua pilihan Give up or get up.

MR : "Jadi di titik terendah itu, disaat Anda merasa berdarah-darah, sedih, kecewa. Ingat Anda mungkin tidak punya jawaban, tapi Anda punya pilihan, dan pilihan itu cuma dua give up or get up. Menyerah dan membiarkan diri Anda terpuruk di lembah kekelaman itu atau bangkit, bangkit dari kenyataan itu, hadapi kepahitan itu dan biarkan masa depan akan jauh lebih baik lagi. Dan biarkan Anda let go and move on, dan kembali ke hidup Anda.

IJ :"Jadi setelah berada dalam lembah kekelaman, masalah yang berat, sekarang sudah mulai menemukan titik cerah ya miss." (Imk/AJ/Drk/SBPJ/3/05.49$06.50)$

Tuturan bernomor 5 tersebut, dituturkan Merry Riana untuk menjelaskan quotes yang dibacakan oleh Ibnu Jamil. Berdasarkan tuturan tersebut, jenis implikaturnya 
konvensional karena apa yang dituturkan Merry Riana "Jadi di titik terendah itu, disaat Anda merasa berdarah-darah, sedih, kecewa. Ingat Anda mungkin tidak punya jawaban, tapi Anda punya pilihan, dan pilihan itu cuma dua give up or get up. Tuturan tersebut bermaksud ketika berada di keadaan tersulit, terpuruk hanya memiliki dua pilihan bangkit atau menyerah.

Tuturan tersebut dapat dipahami oleh Ibnu Jamil dari responnya menjawab tuturan tersebut dengan jawaban "Jadi setelah berada dalam lembah kekelaman, masalah yang berat, sekarang sudah mulai menemukan titik cerah ya miss". Berdasarkan jenis modusnya yakni imperatif perintah, berarti tuturan tersebut memiliki fungsi tuturan direktif yang berupa memerintah.

Berbeda dengan tuturan yang bernomor 5 tuturan berikut juga memiliki imperatif ajakan yang diambil pada acara Metro Tv I'm Impossible dengan tema Kegedan Gengsi part yang berbeda yaitu part 4 yang berjudul "Ini Yang Akan Membentuk Karaktermu" seperti di bawah ini;

12. MR : "Merapikan tempat tidur kita itu penting, karena sesuatu yang kita ulang-ulang setiap hari itu akan membentuk karakter kita. Makna dari merapikan tempat tidur adalah kita berhasil menyelesaikan tanggun jawab kita di hari itu...." IF : "Ternyata dari hal kecil itu bisa membentuk karakter kita ya."

(Imk/Aj/Rps/KGGS/1/08.48-

Tuturan yang bernomor 12 tersebut, dituturkan oleh Merry Riana untuk setelah menanyakan Ke Audien "di lagu bangun tidur habis mandi ku tolong Ibu, yaitu apa? Audien menjawab "membersihkan temat tidur". Kemudian Merry Riana menuturkan tuturan yang bernomor 12 tersebut.

Berdasarkan tuturan tersebut, jenis implikaturnya konvensional karena tuturan Merry Riana "Merapikan tempat tidur kita itu penting, karena sesuatu yang kita ulang-ulang setiap hari itu akan membentuk karakter kita. Makna dari merapikan tempat tidur adalah kita berhasil menyelesaikan tanggung jawab kita di hari itu...." Termasuk implikatur konvensional karena Irgi Fahrezi (pembawa acara) dapat memahami maksud dari tuturan Merry Riana tersebut dengan menjawab "Ternyata dari hal kecil itu bisa membentuk karakter kita ya."

Tuturan tersebut bermodus imperatif ajakan yang berupa ajakan untuk merapikan tempat tidur setelah bangun tidur. Fungsi tuturan tersebut representatif yang berupa menyebutkan kebenaran bahwa merapikan tempat tidur sebuah hal yang harus dibiasakan setiap hari sebagai cara untuk menyelesaikan tanggung jawab di hari itu, sehingga pekerjaan lain yang berat juga akan terselesaikan karena sudah terbiasa melakukan hal kecil seperti merapikan tempat tidur.

\section{Implikatur Konvensional Bermodus Imperatif Permintaan}

Kalimat imperatif permintaan merupakan kalimat imperatif dengan kadar suruhan lebih halus dariada imperatif perintah. Pada tuturan imperatif yang mengandung makna pragmatik imperatif permintaan biasanya ditandai dengan penanda kalimat tolong atau frasa yang 
bermakna (tolong, minta, mohon). Pada tuturan imperatif yang mengandung makna permohonan biasanya ditandai dengan ungkapan penanda kesantunan mohon. Selain ditandai dengan hadirnya penanda kesantunan itu, partikel -lah juga digunakan untuk memperhalus kadar tuturan imperatif permohonan.

Berikut adalah tuturan atau kalimat yang mengandung imperatif permintaan.

1. MR : "Bayangkan Anda berada di Rumah Sakit, terus ada mesin pendeteksi jantung yang menempel di tubuh anda, terus Anda melihat di monitor. Pilih mana yang gambarnya naik turun apa pilih yang datar-datar aja. Pilih yang mana?"

AU : "Naik turun."

MR : "Benar banget, kalau datar berarti artinya kita day alias sudah tidak di dunia lagi."

(Imk/Pm/Rps/SBPJ/1/05.29-

Tuturan yang bernomor 1 tersebut dituturkan oleh Merry Riana di acara I'm Impossible yang bertema Sedih Boleh Putus Asa Jangan part 1 dengan judul "Bersyuku Ketika Ada Masalah". Tuturan tersebut dituturkan ketika Merry Riana menjelaskan bahwa hidup itu tidak akan datar-datar aja seperti diibaratkan dengan mesin pendeteksi jantung, karena jika datardatar aja maka artinya mati.

Berdasarkan tuturan tersebut jenis implikaturnya konvensional karena Audien memahami maksud dari tuturan Merry Riana "Bayangkan Anda berada di Rumah Sakit, terus ada mesin pendeteksi jantung yang menempel di tubuh anda, terus Anda melihat di monitor. Pilih mana yang gambarnya naik turun apa pilih yang datar-datar aja. Pilih yang mana?".

Maksud dari tuturan Merry Riana tersebut ialah memancing pengetahuan Audien mau pilih hidup atau mati dengan mengambil contoh mesin pendeteksi jantung yang gambarnya naik turun atau datar. Audien memahami apa yang dituturkan Merry Riana sehingga Audien menjawab tuturan Merry Riana dengan jawaban "Naik turun." Audien memahami bahwa gambar yang dimaksud Merry Riana seperti yang ada di monitor alat pendeteksi jantung menandakan bahwa hidup itu ada kalanya di atas dan di bawah, jika Audien mau meilih datar yang berarti mati tentu saja tidak akan memiliki masalah dalam hidupnya.

Modus tuturan tersebut imperatif permintaan yaitu permintaan yang diberikan untuk Audien, mau memilih gambar yang naik turun atau datar. Fungsi tuturan tersebut representatif yang berupa menyatakan peristiwa yaitu bahwa pada alat pendekteksi jantung memiliki gambar di monitornya naik turun dan datar, naik turun berarti masih hidup dan datar berarti sudah mati.

Berbeda dengan tuturan yang bernomor 1, tuturan berikut juga memiliki imperatif permintaan yang diambil pada acara Metro Tv I'm Impossible dengan tema Ibu Rumah Tangga Vs Ibu Bekerja part 1 yang berjudul "Pilih Ibu Rumah Tangga Atau Ibu Bekerja "seperti di bawah ini;

18. MR : "Ibu bekerja atau Ibu rumah tangga. Jadi sekali lagi benar-benar dipikirkan apakah ini sebuah keharusan atau sebuah tuntutan atau masih menjadi sebuah pilihan." AU : “Ok." (Tepuk tangan) 
(Imk/Pm/Drk/IRIB/1/09.43-

Tuturan yang bernomor 18 dituturkan oleh Merry Riana ketika menjelaskan bahwa banyak wanita yang dikodratkan sebagai seorang Ibu itu harus memikirkan baik-baik pilihanya mau menjadi Ibu rumah tangga aja atau Ibu yang bekerja.

Berdasarkan tuturan tersebut, jenis implikaturnya konvensional karena Audien memahami maksud dari tuturan Merry Riana yang menuturkan "Jadi sekali lagi benar-benar dipikirkan apakah ini sebuah keharusan atau sebuah tuntutan atau masih menjadi sebuah pilihan."

Maksud dari tuturan tersebut yaitu mau menjadi ibu bekerja atau ibu rumah tangga harus benar-benar dipikirkan itu karena keharusan misalnya alasan memilih bekerja karena suami lagi sakit, atau sebuah tuntutan misalnya untuk memenuhi kebutuhan hidup atau bahkan masih menjadi sebuah pilihan. Menjadi ibu rumah tangga pun harus dipirkan juga, apakah menjadi keharusan dengan alasan anak yang berada di usia yang memerlukan perhatian khusus, atau menjadi tuntutan misalkan karena anak sakit sehingga harus didampingi dan dirawat, bahkan menjadi pilihan. Apapun yang akan dipilih perlu dipikirkan secara baik-baik.

Tuturan tersebut bermodus imperatif permintaan yang berupa permintaan agar memikirkan secara benar-benar ketika mau memutuskan untuk menjadi ibu rumah tangga atau ibu bekerja. Fungsi tuturan tersebut direktif yang berupa memerintah, yaitu memerintahkan agar sebelum memutuskan menjadi ibu rumah tangga atau menjadi ibu bekerja memiliki alasan yang tepat apakah sebuah keharusan, tuntutan dan pilihan.

Berbeda dengan tuturan yang bernomor 18 tuturan berikut juga memiliki imperatif permintaan yang diambil pada acara Metro Tv I'm Impossible dengan tema Maju Terus Pantang Mundur part 4 yang berjudul "Ini Alasan Kenapa Kamu Harus Tetap Maju" seperti di bawah ini;

26. HS : "Saya ingin bertanya nih Miss Merry, saya mempunyai bisinis atau usaha baru tapi saya punya kendala keluarga kurang support, saya bingung dan ragu miss untuk melanjutkannya. Menurut Miss Merry saya harus stop karena keluarga saya atau lanjut dan membuktikkan ke keluarga saya kalau saya bisa gitu Miss?" MR : "Sebelum saya jawab, saya mau tanya ya mas Henri. Yang jalani hidupnya siapa?"

HS : "Saya sendiri."

MR : "Yang kalau gagal konsekuensinya ke siapa?"

HS : "Saya sendiri."

MR : "Yang kalau sukses untuk siapa?"

HS : "Saya sendiri."

MR : "Kalo gitu yang nentuin siapa?"

HS : "Saya sendiri."

MR : "Nah, jawabannya ada pada diri sendiri."

(Imn/Pm/Drk/MTPM/4/03.15-

Tuturan yang bernomor 26 tersebut ditutrkan oleh Merry Riana ketika ada salah satu Audien yaitu Henri Sutono yang bertanya kepada Merry Riana, bahwa Henri merasa bingung ketika Ia tidak mendapatkan dukungan dari keluarganya. 
Berdasarkan tuturan tersebut, jenis implikaturnya konvensional karena Merry Riana menjawab pertanyaan Henri dengan pertanyaanpertanyaan, dari pertanyaan tersebut Henri memahami bahwa jawaban dari pertanyaannya sudah terjawab dengan sesuai dengan jawaban Henri.

Tuturan tersebut bermodus imperatif permintaan yang berupa permintaan kepada Henri untuk menjawab apa yang ditanyakan Merry Riana. Fungsi tuturannya termasuk direktif yaitu memerintahkan kepada Henri untuk menjawab apa yang ditanyakan dengan mencari jawaban pada diri sendiri, karena yang menjalani juga Henri sendiri, jadi yang memutuskan juga Henri sendiri.

\section{Relevansi Implikatur Konvensional Bermodus Imperatif pada Tuturan} Motivasi Merry Riana terhadap Pembelajaran Bahasa Indonesia

Penggunaan implikatur dalam berbahasa sengaja dilakukan dengan pertimbangan tersendiri, seperti memperhalus tuturan, menjaga etika kesopanan, dan menjaga agar tidak menyinggung perasaan pendengar ataupun mitra tutur secara langsung. Lebih lanjut, Grice (dalam Rohmadi 2017:60) menyatakan bahwa implikatur konvensional tergantung pada kondisi kebenaran dalam penggunaan kata atau makna, bentukbentuk tertentu dan ekspresi dari suatu tuturan dalam percakapan. implikatur konvensional bersifat umum yang artinya secara umum orang sudah mengetahui maksud dan makna sesuatu hal tersebut dalam suatu tuturan.

Dalam pembelajaran Bahasa Indonesia, hasil analisis tentang implikatur konvensional bermodus imperatif pada tuturan motivasi Merry Riana ini dapat digunakan sebagai alternatif bahan ajar dalam pembelajaran teks pidato persuasif. Hal tersebut sesuai dengan tujuan dari pidato persuasif, yaitu meyakinkan audiensi untuk melakukan Sesuatu (Trianto, dkk, 2018:35). Dalam buku siswa terbitan pemerintah edisi revisi 2018 tersebut, siswa diajak untuk belajar tentang teks pidato persuasif yang merupakan salah satu dari teks eksposisi. Siswa diharapkan mampu membuat teks pidato yang dapat mempengaruhi penyimak agar melakukan hal-hal yang terkandung dalam pidato tersebut. Oleh sebab itu, hasil analisis tuturan motivasi Merry Riana ini relevan untuk dijadikan alternatif contoh atau bahan ajar dalam pembelajaran teks pidato persuasif yang terdapat pada materi SMP kelas IX KD 3.3., 4.3., 3.4. dan 4.4.

\section{PENUTUP}

Berdasarkan hasil pembahasan, dikethui bahwa terdapat tiga jenis implikatur konvensional bermodus imperatif pada tuturan motivasi Merry Riana, yaitu perintah, ajakan, dan permintaan. Di antara ketiganya, yang paling dominan adalah perintah. Artinya, secara tidak langsung Marry Riana berhasil memotivasi dengan Bahasa yang lebih halus bermodus perintah namun tidak terkesan memerintah. Dalam pembelajaran Bahasa Indonesia, implikatur konvensional bermodus imperatif pada tuturan motivasi Merry Riana ini relevan dengan salah satu pokok bahasan untuk mendukung tercapainya KD 3.3., 4.3., 3.4. dan 4.4 yang berkaitan dengan pidato persuasif di kelas IX SMP.

\section{DAFTAR PUSTAKA}

Aeni, Albani Nur. (2015). Analisis Implikatur pada Tuturan Kata 
Bijak Mario Teguh dalam Acara Talk Show Mario Teguh Golden Ways di Metro TV. Bandar Lampung: Universitas Lampung.

Gerungan, W.A. (1991). Psikologi Sosial. Bandung : Eresco.

Grice, H. P. (1975). Logic and conversation. New York: Academic Press.

Khasanah, Eva Nur. (2016). Implikatur dan Daya Pragmatik di Balik Ungkapan Motivasi Berorganisasi Kalangan Peserta Didik. Surakarta: Universitas Muhammadiyah Surakarta.

Lyons, John. (1995). Pengantar Teori Linguistik. Jakarta : Gramedia Pustaka.

Mulyana, Dedy. (2005). Ilmu Komunikasi Suatu Pengantar. Bandung: PT Remaja Rosdakarya.
Rani, A. Arifin, B. dan Martutik. (2004). Analisis Wancana Sebuah Kajian Bahasa dalam Pemakaian. Malang : Bayumedia Publishing.

Rohmadi, Muhammad. (2017) Pragmatik Teori dan Anaslisis. Surakarta: Yuma Pusaka.

Sadirman, A.M. (2006). Interaksi dan Motivasi Belajar Mengajar. Jakarta: Grafindo.

Triyanto, Agus, dkk. (2018). Bahasa Indonesia. Jakarta: Pusat Kurikulum dan Perbukuan, Balitbang, Kemendikbud.

Wijana, I Dewa putu. (1996). Dasardasar Pragmatik. Yogyakarta: Andi Offset.

Yule, George. (1998). Pragmatik. Jakarta : Pustaka Belajar. 